\title{
ANALISIS EKSPLORASI DAN VISUALISASI PROFIL SUPERHOST AIRBNB KOTA MADRID DAN AMSTERDAM
}

\author{
Irwan Setiawan ${ }^{1}$ \\ ${ }^{1}$ Jurusan Teknik Komputer dan Informatika Politeknik Negeri Bandung \\ Email: 1irwan@jtk.polban.ac.id
}

\begin{abstract}
Abstrak
Superhost Airbnb merupakan host yang berpengalaman dan memberikan layanan yang sangat baik kepada para konsumennya. Superhost memiliki keistimewaan yang dapat meningkatkan jumlah pesanan dan pendapatannya. Profil superhost menjadi salah satu hal yang dapat dijadikan rujukan bagi host yang lain dalam rangka meningkatkan kualitas layanannya. Pada penelitian ini dilakukan analisis ekplorasi dan visualisasi data host Airbnb kota Amsterdam dan kota Madrid untuk mengetahui profil dari superhost berdasarkan aspek harga dan ulasan konsumen. Pemilihan kota Amsterdam dan kota Madrid dikarenakan kedua kota tersebut merupakan kota tujuan utama wisatawan di Eropa. Penelitian dilakukan dengan menggunakan pendekatan machine learning yang memiliki empat langkah pengerjaan, yaitu pemahaman proses bisnis, pengambilan data, pemrosesan data, dan analisis eksplorasi dan visualisasi data. Tools yang digunakan dalam penelitian ini adalah Jupyter Notebook dengan bahasa pemrograman Python. Hasil yang didapatkan dari penelitian ini adalah superhost di kota Madrid paling banyak menawarkan harga sewa pada rentang harga $\$ 60$ - $\$ 80$. Superhost pada rentang harga tersebut mendapatkan ulasan paling tinggi dari pelanggan berdasarkan kebersihan, komunikasi, dan check-in. Sedangkan untuk kota Amsterdam, superhost paling banyak menawarkan harga sewa pada rentang harga diatas \$140. Superhost pada rentang harga tersebut mendapatkan ulasan paling tinggi dari pelanggan pada semua kelompok ulasan.
\end{abstract}

Kata Kunci: Airbnb, analisis, profil, superhost, visualisasi

\begin{abstract}
Superhost Airbnb is an experienced host and provides excellent service to its customers. Superhost has features that can increase the number of bookings and revenue. SuperHost profile is one thing that can be used as a reference for other hosts to improve the quality of service. In this study, an analysis of exploration and visualization of Airbnb hosts' data in the city of Amsterdam and the city of Madrid to find out the profile of superhost from the aspect of price and consumer reviews. The city of Amsterdam and the city of Madrid are chosen because the two cities are the leading destinations for tourists in Europe. The study was conducted using a machine learning approach that has four work steps, namely understanding business processes, data retrieval, data processing, and exploratory analysis and data visualization. The tools used in this study are Jupyter Notebook with the Python programming language. The results obtained from this study are superhost in Madrid, mostly offering rental prices in the price range of $\$ 60$ - $\$ 80$. They get the highest reviews from customers based on cleanliness, communication, and check-in. As for Amsterdam, the superhost offers the most rental prices in the price range above \$140. Superhosts in this price range gets the most reviews from customers in all review groups.
\end{abstract}

Keywords: Airbnb, analysis, profile, superhost, visualization 


\section{PENDAHULUAN}

Superhost merupakan status yang diberikan Airbnb kepada host yang berpengalaman dan memberikan layanan yang sangat baik kepada para konsumennya (Gunter, 2018). Airbnb akan mengevaluasi kinerja Superhost empat kali dalam setahun untuk memastikan setiap Superhost memberikan layanan terbaik untuk setiap pelanggannya. Host yang memiliki status sebagai Superhost memiliki beberapa keistimewaan, antara lain adalah label Superhost dapat dilihat dengan jelas oleh calon konsumen potensial sebagai tanda kualitas akomodasi dan komitmen dari host. Hal ini akan meningkatkan jumlah pemesanan dan meningkatkan pendapatan dari host tersebut (Liang dkk., 2017).

Keistimewaan yang dimiliki oleh superhost menjadi tujuan dari host-host lainnya, baik yang sudah lama terdaftar di Airbnb ataupun host baru. Profil superhost menjadi salah satu hal yang dapat dijadikan rujukan bagi host yang lain dalam rangka meningkatkan kualitas layanannya. Kota Amsterdam, Berlin, London, dan Madrid merupakan empat kota utama di benua Eropa yang menjadi tujuan wisata (Gunter, 2018).

Salah satu cara untuk mengetahui profil dari superhost adalah dengan menggunakan teknik analisis eksplorasi dan visualisasi data. Analisis eksplorasi dan visualisasi data telah banyak digunakan dalam berbagai penelitian untuk membantu para pengambil keputusan dalam menentukan strategi bisnis (Diamond \& Mattia, 2017). Teknik ini juga digunakan pada penelitian lain seperti analisis host liburan singkat di Singapura (Setiawan, 2020), memetakan ketersediaan Airbnb di kota-kota di Eropa (Adamiak, 2018), memodelkan permintaan Airbnb di kota New York (Gunter dkk., 2020), dan visualisasi pengalaman tamu (Sutherland \& Kiatkawsin, 2020). Analisis eksplorasi dan visualisasi data dapat dilakukan dengan menggunakan berbagai tool. Beberapa tool yang dapat digunakan untuk melakukan analisis eksplorasi dan visualisasi data adalah python (Kui dkk., 2017), $R$ (Brownstein dkk., 2019), dan Tableau (Hoelscher \& Mortimer, 2018).

Pada penelitian ini dilakukan analisis eksplorasi dan visualisasi data superhost Airbnb dari kota Amsterdan dan Madrid dari aspek harga dan ulasan konsumen dengan harapan profil superhost yang didapatkan dari kedua kota tersebut dapat menjadi model untuk kota-kota lainnya. Tool yang digunakan pada penelitian ini adalah Jupyter Notbook dengan menggunakan bahasa Python.

\section{METODE}

Rancangan penelitian terdiri dari empat tahapan. Seperti dapat dilihat pada Gambar, tahapan pertama adalah pemahaman proses bisnis. Pada tahapan ini dilakukan kajian Pustaka dan penelusuran dokumen yang berkaitan dengan proses bisnis peer-to-peer rental, khususnya Airbnb.

Tahapan kedua adalah pengambilan data yang berkaitan dengan host Airbnb. Data untuk penelitian ini diambil dari website insideairbnb.com yang menyediakan data hasil scraping dari site Airbnb. Pada penelitian ini digunakan dataset listings_detailed.csv untuk kebutuhan analisis kota Madrid dan listings_details.csv untuk kota Amsterdam. Dataset Madrid memiliki 20.837 baris dan 106 atribut dengan ukuran file $76.391 \mathrm{~KB}$ sedangkan dataset Amsterdam memiliki 20.030 baris dan 96 atribut dengan ukuran file $79.326 \mathrm{~KB}$.

Tahap ketiga adalah pemrosesan data. Data yang sudah didapatkan perlu dipastikan kesiapan datanya untuk kebutuhan analisis lebih lanjut (Setiawan, 2020). Pada tahapan ini terdapat tiga sub tahapan pekerjaan, yaitu pembersihan data, filterisasi data, dan agregasi data. Pembersihan data dilakukan untuk menghilangkan anomali dan mendapatkan koleksi data yang merupakan representasi dunia nyata (Ridzuan \& Wan Zainon, 2019). Pemfilteran data dilakukan untuk memfilter data yang akan digunakan dalam penelitian.

Pada penelitian ini hanya digunakan 16 atribut. Pemilihan atribut disesuaikan dengan tujuan penelitian yang lebih berfokus kepada profil superhost berdasarkan biaya dan ulasan dari pelanggan. Seperti dapat dilihat pada Tabel, atribut-atribut yang berkaitan dengan harga, seperti price, cleaning_fee, security_deposit, dan extra_people memiliki tipe data object dikarenakan terdapat tanda "\$" pada setiap nilainya. Pada atribut-atribut ini dilakukan penghilangan karakter "\$" dan pengubahan tipe data menjadi float64.

Berkenaan dengan nilai NULL (missing value), seperti dapat dilihat pada Tabel, terdapat 10 atribut yang memiliki nilai $N U L L$ dengan jumlah yang beragam. Atribut security_deposit dan cleaning_fee memiliki jumlah NULL yang paling banyak. Untuk kedua atribut ini, penulis mengganti nilai NULL dengan angka 0 (nol) dengan asumsi host tidak memintakan biaya 
security_deposit dan cleaning_fee kepada calon konsumennya. Nilai NULL pada atribut bathrooms, bedrooms, beds, dan host_is_superhost dihilangkan dari dataset dikarenakan jumlahnya yang sangat sedikit sehingga tidak akan mengganggu hasil analisis. Untuk nilai NULL pada atribut review_scores_location,

review_scores_communication,

review_scores_cleanliness

dan

review_scores_checkin, tidak dilakukan aksi apapun dikarenakan dimungkinkan konsumen tidak memberikan ulasan.

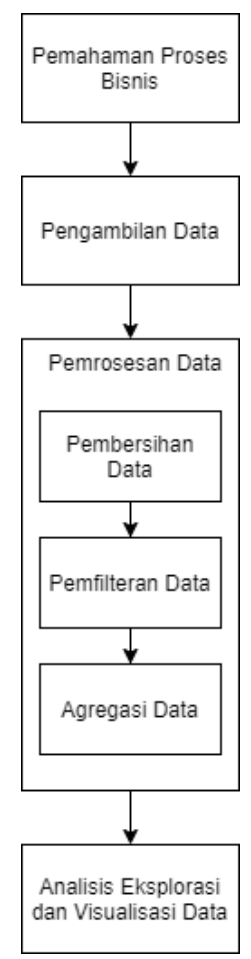

Gambar 1. Langkah pengerjaan

Berkenaan dengan atribut price, penulis membuat atribut baru untuk mengelompokkan harga kedalam delapan kelompok, yaitu kelompok harga "0-20", "20-40", "40-60", "60-80", "80100", "100-120", "120-140", dan "140+". Setelah dilakukan pemrosesan data, dataset kota Madrid terdiri dari 20.758 baris dan 17 atribut, sedangkan dataset kota Amsterdam terdiri dari 20.000 baris dan 17 atribut.

Tahap terakhir adalah analisis ekplorasi dan visualisasi data. Pada tahapan ini dilakukan analisis secara ekplorasi dan visualisasi terhadap atribut-atribut yang berkaitan dengan harga dan ulasan konsumen. Temuan-temuan yang didapatkan pada tahap ini dibahas pada bagian hasil dan pembahasan pada artikel ini. Tahapan pemrosesan data dan analisis eksplorasi dan visualisasi data dilakukan dengan menggunakan Bahasa Python dengan tool jupyter notebook.

Tabel 1. Daftar Atribut Dataset

\begin{tabular}{|c|c|c|}
\hline No & Nama Atribut & Tipe Data \\
\hline 1 & neighbourhood_cleansed & object \\
\hline 2 & property_type & object \\
\hline 3 & room_type & object \\
\hline 4 & price & object \\
\hline 5 & cleaning_fee & object \\
\hline 6 & host_is_superhost & object \\
\hline 7 & bathrooms & float64 \\
\hline 8 & security_deposit & object \\
\hline 9 & extra_people & object \\
\hline 10 & guests_included & int64 \\
\hline 11 & bedrooms & float64 \\
\hline 12 & beds & float64 \\
\hline 13 & review_scores_cleanliness & float64 \\
\hline 14 & review_scores_checkin & float64 \\
\hline 15 & review_scores_communication & float64 \\
\hline 16 & review_scores_location & float64 \\
\hline
\end{tabular}

Tabel 2. Missing Value Dataset Madrid dan Amsterdam

\begin{tabular}{|l|l|r|r|}
\hline No & \multicolumn{1}{|c|}{ Nama Atribut } & $\begin{array}{r}\text { Jumlah } \\
\text { (Madrid) }\end{array}$ & $\begin{array}{c}\text { Jumlah } \\
\text { (Amster } \\
\text { dam) }\end{array}$ \\
\hline 1 & security_deposit & 6.921 & 6.166 \\
\hline 2 & cleaning_fee & 5.257 & 3.629 \\
\hline 3 & ulasan_scores_location & 4.968 & 2.661 \\
\hline 4 & ulasan_scores_checkin & 4.965 & 2.660 \\
\hline 5 & ulasan_scores_cleanliness & 4.962 & 2.652 \\
\hline 6 & ulasan_scores_communication & 4.961 & 2.647 \\
\hline 7 & beds & 51 & 10 \\
\hline 8 & host_is_superhost & 15 & 8 \\
\hline 9 & bathrooms & 10 & 7 \\
\hline 10 & bedrooms & 9 & 4 \\
\hline
\end{tabular}

\section{HASIL DAN PEMBAHASAN}

Terdapat empat tipe ruangan yang didefinisikan dalam Airbnb, yaitu private room, entire homelapartment, hotel room, dan shared room. Berdasarkan data yang ada, entire home/apartment merupakan tipe ruangan yang paling banyak disediakan. Jumlah superhost di kota Madrid lebih banyak dari kota Amsterdam, seperti ditunjukkan pada 2, dimana kota Madrid memiliki 20\% superhost dan kota Amsterdam 16\% superhost. Hal yang cukup menarik adalah proporsi jumlah tipe ruangan di kedua kota. Kota Madrid memiliki 
proporsi entire home/apartment sebanyak 60,5\%, private room sebanyak 35,9\%, hotel room sebanyak 2,2\%, dan shared room sebanyak 1,3\%. Sedangkan kota Amsterdam hanya memiliki tiga tipe ruangan saja, yaitu entire home/apartment sebanyak $79,4 \%$, private room sebanyak $20,3 \%$, dan shared room sebanyak $0,3 \%$.

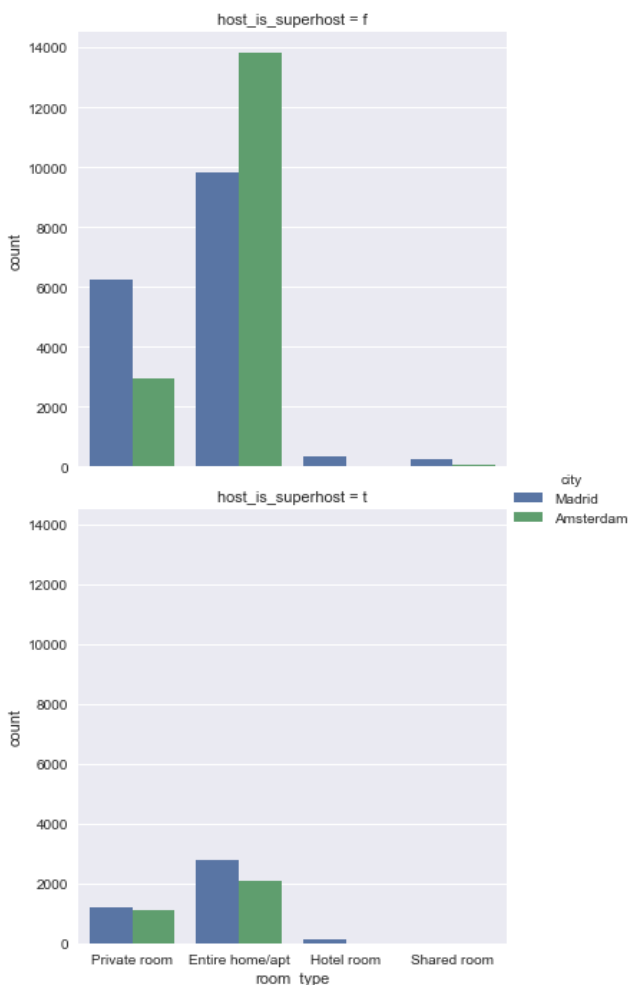

Gambar 2. Proporsi superhost berdasarkan tipe ruangan per kota

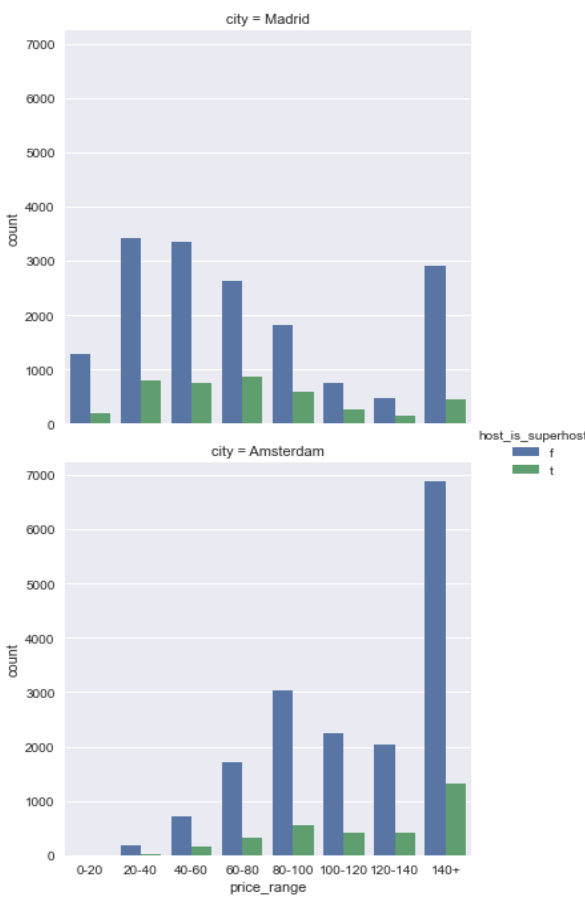

Gambar 3. Proporsi superhost berdasarkan harga sewa ruangan di kota Amsterdam dan Madrid
Profil host dan superhost berdasarkan aspek harga sewa ruangan, seperti dapat dilihat pada Gambar, superhost di kota Madrid menyewakan ruangannya pada rentang harga $\$ 60$ - $\$ 80$ dengan proporsi $21,4 \%$ pada rentang harga $\$ 20$ - \$40 dengan proporsi $19,3 \%$, dan $18,5 \%$ pada rentang harga diatas $\$ 60$ - $\$ 80$. Sedangkan untuk kota Amsterdam, 41,4\% menawarkan harga sewa ruangan pada rentang harga diatas $\$ 140$ dan $17,5 \%$ pada rentang harga $\$ 80$ - \$100. Dari Gambar, dapat dilihat bahwa host yang menawarkan harga sewa dibawah $\$ 140$ belum banyak yang memberikan kualitas layanan yang baik bagi para konsumennya.

Profil berdasarkan aspek ulasan terhadap lokasi yang diberikan oleh konsumen, seperti ditunjukkan pada Gambar 4, host yang menawarkan harga sewa pada rentang harga $\$ 40$ - \$60 mendapatkan nilai ulasan yang paling tinggi. Sedangkan superhost yang mendapatkan ulasan paling tinggi berada pada rentang harga $\$ 60$ - $\$ 80$.

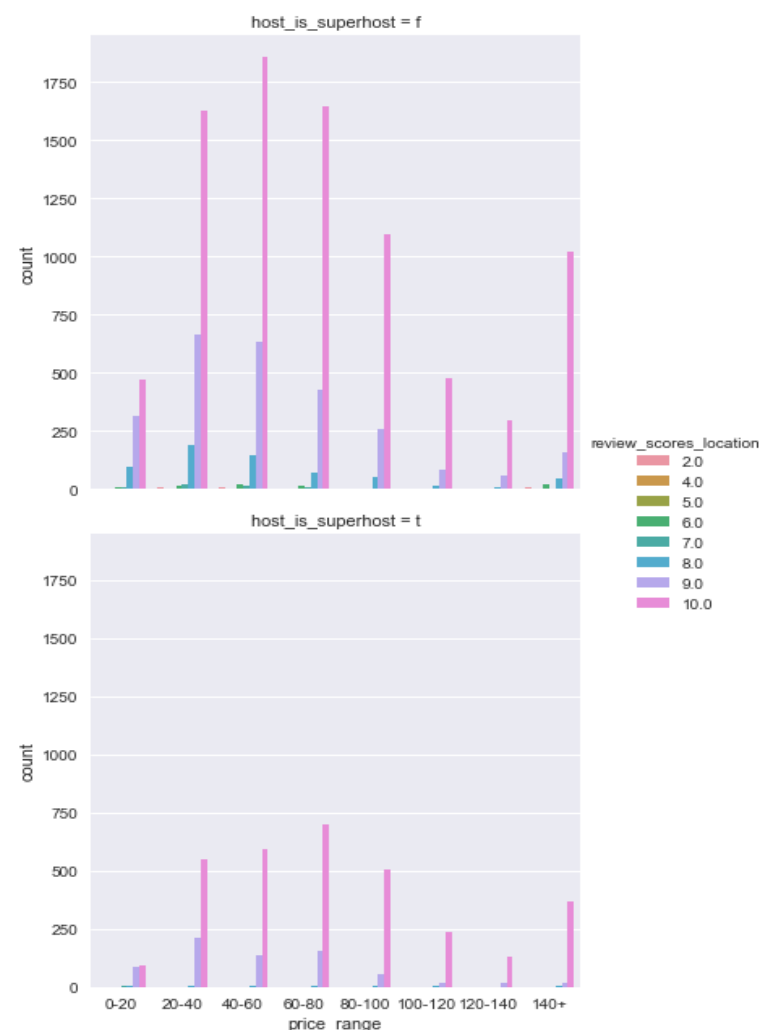

Gambar 4. Proporsi host dan superhost berdasarkan ulasan lokasi di kota Madrid

Untuk kota Amsterdam, ditunjukkan pada Gambar 5, host dan superhost pada rentang harga diatas \$140 mendapatkan ulasan berdasarkan lokasi paling tinggi. Hal ini menunjukkan bahwa lokasi host pada rentang harga dibawah \$140 kurang sesuai dengan harapan konsumen. 


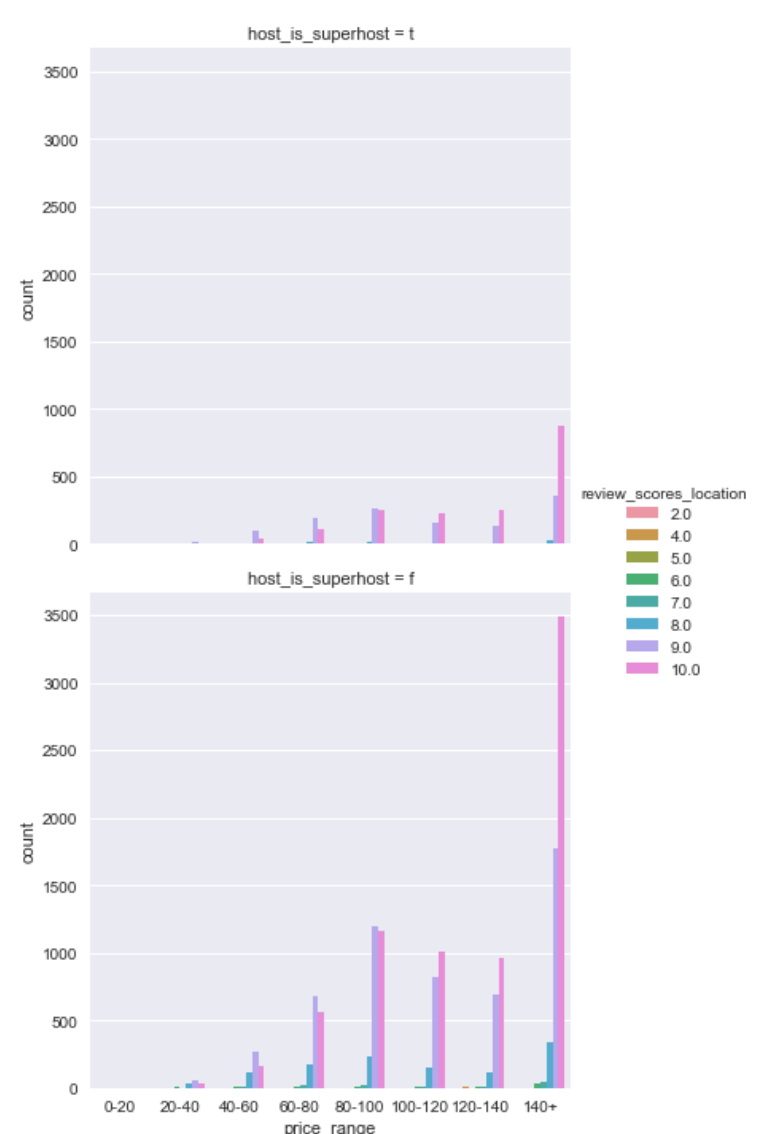

Gambar 5. Proporsi host dan superhost berdasarkan ulasan lokasi di kota Amsterdam

Profil berdasarkan aspek ulasan terhadap kebersihan ruangan yang diberikan oleh konsumen, seperti ditunjukkan pada Gambar 6, host yang menawarkan harga sewa pada rentang harga \$20 $\$ 40$ mendapatkan nilai ulasan yang paling tinggi. Sedangkan superhost yang mendapatkan ulasan paling tinggi berada pada rentang harga $\$ 60$ - $\$ 80$.

Untuk kota Amsterdam, ditunjukkan pada Gambar 7, host dan superhost pada rentang harga diatas \$140 mendapatkan ulasan berdasarkan kebersihan ruangan paling tinggi. Hal ini menunjukkan bahwa kebersihan ruangan host pada rentang harga dibawah $\$ 140$ kurang sesuai dengan harapan konsumen.

Profil berdasarkan aspek ulasan konsumen terhadap komunikasi pemilik ruangan, seperti ditunjukkan pada Gambar 8, host yang menawarkan harga sewa pada rentang harga \$20 $\$ 40$ mendapatkan nilai ulasan yang paling tinggi. Sedangkan superhost yang mendapatkan ulasan paling tinggi berada pada rentang harga $\$ 60$ - $\$ 80$. Untuk kota Amsterdam, ditunjukkan pada Gambar, host dan superhost pada rentang harga diatas \$140 mendapatkan ulasan berdasarkan komunikasi pemilik ruangan paling tinggi.

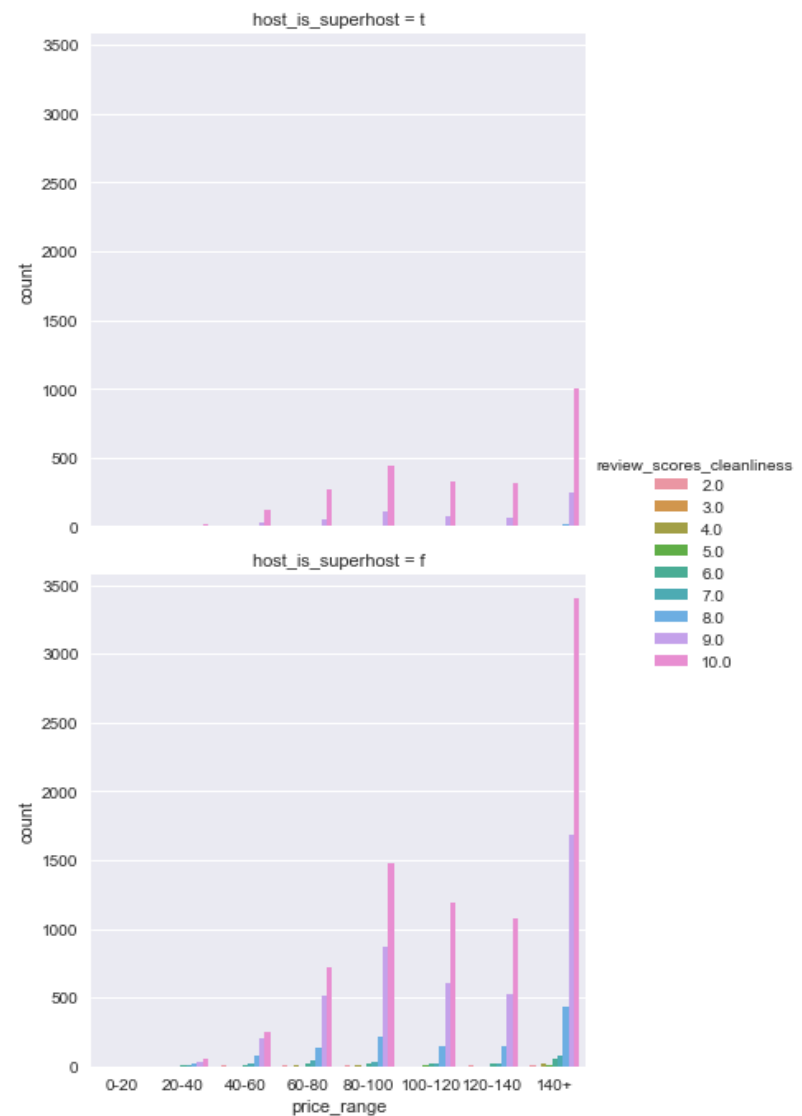

Gambar 6. Proporsi host dan superhost berdasarkan ulasan kebersihan ruangan di kota Amsterdam

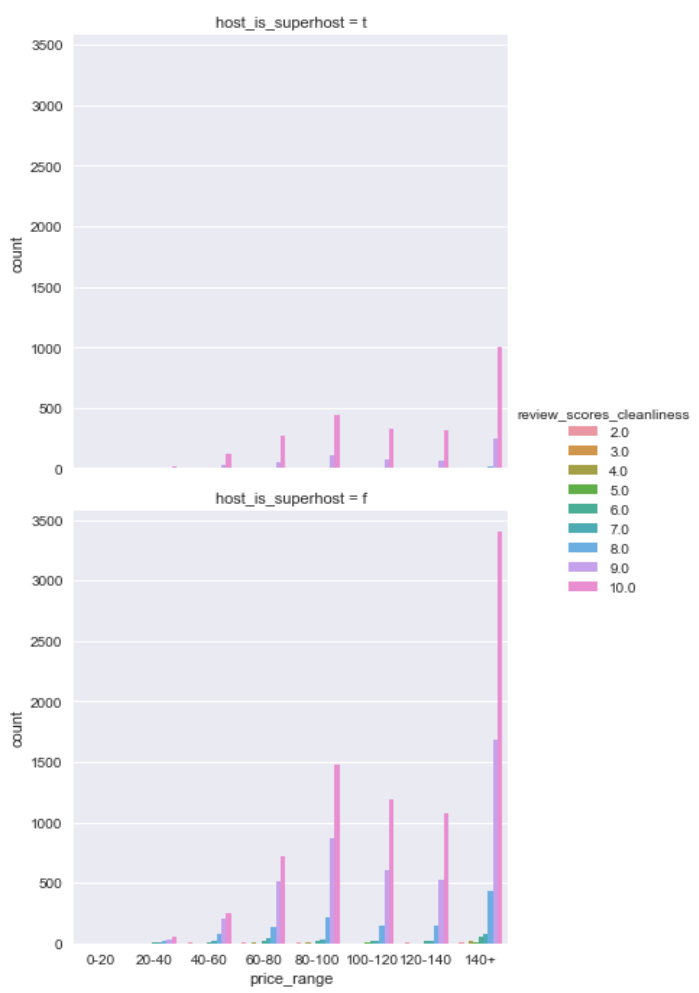

Gambar 7. Proporsi host dan superhost berdasarkan ulasan kebersihan ruangan di kota Amsterdam 


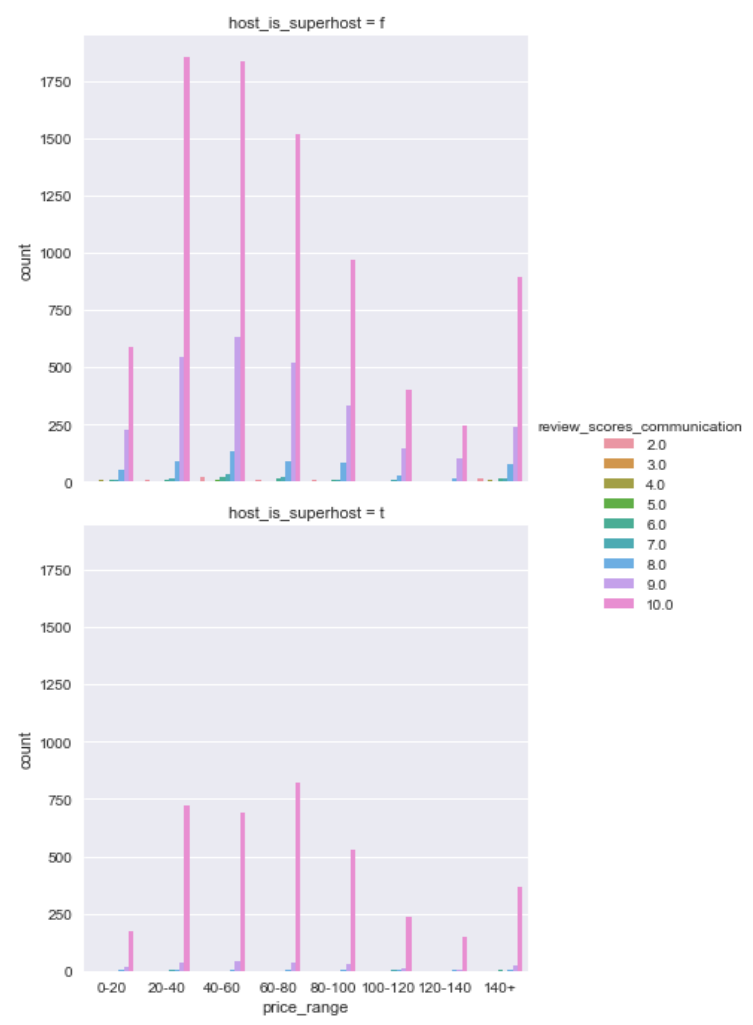

Gambar 8. Proporsi host dan superhost berdasarkan ulasan komunikasi di kota Madrid

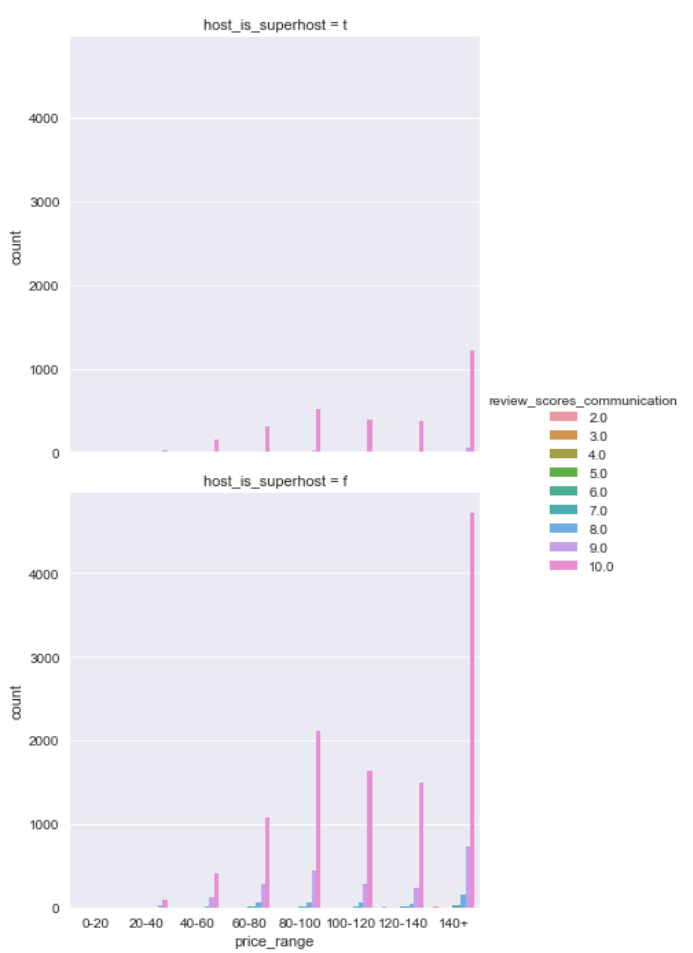

Gambar 9. Proporsi host dan superhost berdasarkan ulasan komunikasi di kota Amsterdam

Profil berdasarkan aspek ulasan terhadap pengalaman check-in yang diberikan oleh konsumen, seperti ditunjukkan pada Gambar 10, host yang menawarkan harga sewa pada rentang harga \$20 - \$40 mendapatkan nilai ulasan yang paling tinggi. Sedangkan superhost yang mendapatkan ulasan paling tinggi berada pada rentang harga $\$ 60$ - $\$ 80$. Untuk kota Amsterdam, ditunjukkan pada Gambar 11, host dan superhost pada rentang harga diatas $\$ 140$ mendapatkan ulasan berdasarkan pengalaman check-in paling tinggi

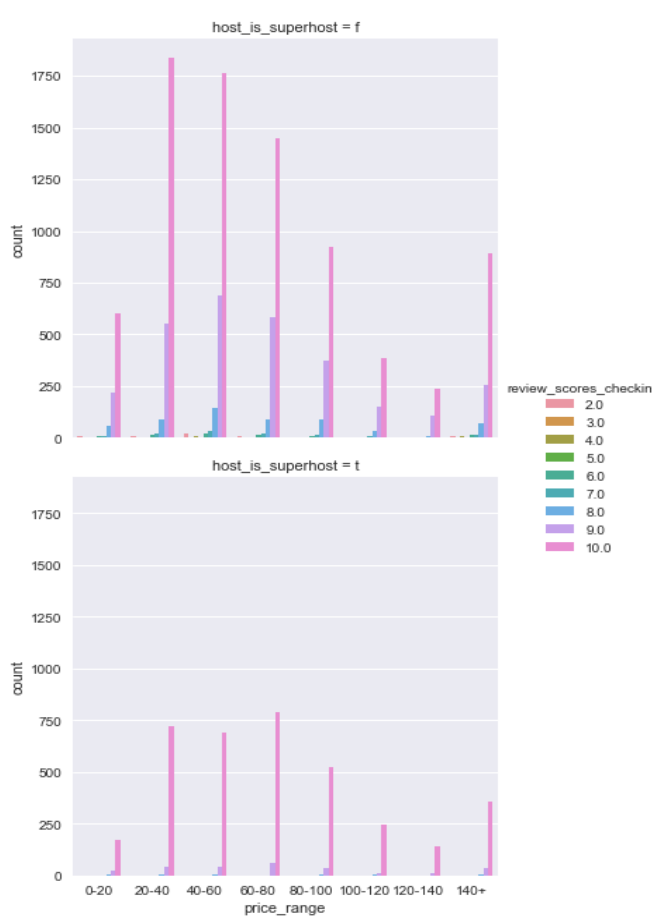

Gambar 10. Proporsi host dan superhost berdasarkan ulasan check-in di kota Madrid

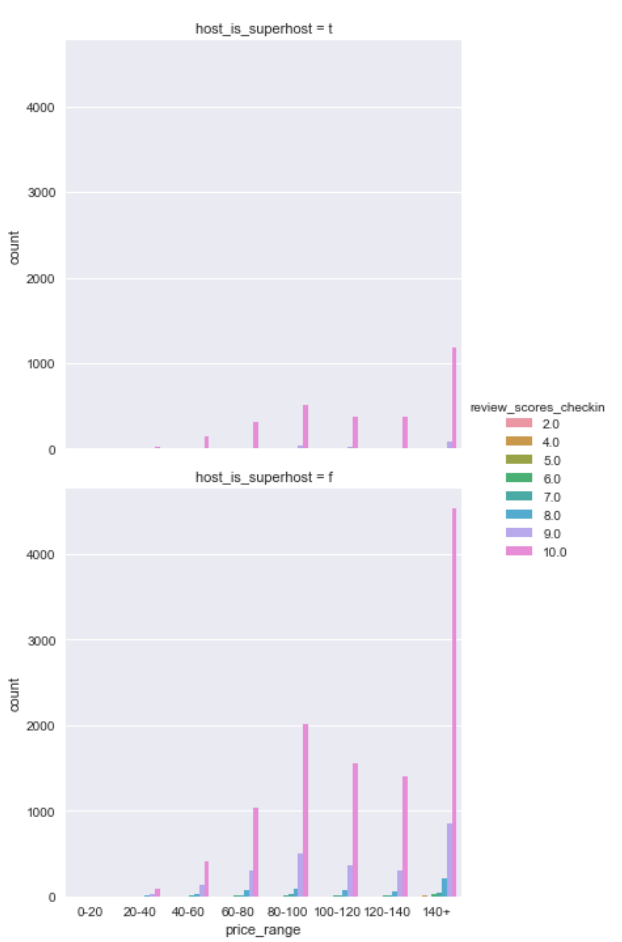

Gambar 11. Proporsi host dan superhost berdasarkan ulasan check-in di kota Amsterdam 


\section{PENUTUP}

\section{Kesimpulan}

Pada penelitian telah dilakukan analisis eksplorasi dan visualisasi data host Airbnb di kota Amsterdam dan kota Madrid untuk mendapatkan profil superhost berdasarkan aspek harga sewa dan ulasan pelanggan. Berdasarkan temuan yang didapatkan, superhost di kota Madrid paling banyak menawarkan harga sewa pada rentang harga $\$ 60$ - \$80. Superhost yang mendapatkan nilai ulasan dari pelanggan dengan nilai tertinggi paling banyak didapatkan oleh superhost yang menawarkan harga sewa pada rentang harga \$60 $\$ 80$.

Untuk kota Amsterdam, superhost paling banyak adalah host yang menawarkan harga sewa pada rentang harga diatas $\$ 140$. Superhost pada rentang harga tersebut juga mendapatkan nilai ulasan dari pelanggan dengan nilai tertinggi yang paling banyak.

\section{Saran}

Penelitian ini baru mengeksplorasi profil superhost berdasarkan aspek harga sewa dan ulasan pelanggan saja. Agar mendapatkan profil superhost yang lebih lengkap, ada baiknya dilihat juga profil superhost berdasarkan aspek lainnya seperti deskripsi ulasan dari pelanggan, jumlah konsumen yang menginap, dan berapa lama konsumen tersebut menginap.

\section{Ucapan Terima Kasih}

Penelitian ini dibiayai oleh DIPA Politeknik Negeri Bandung sesuai dengan Surat Perjanjian Pelaksanaan Penelitian skema Penelitian Pemula (PP) Nomor: B/186.19/PL1.R7/PG.00.03/2020.

\section{DAFTAR PUSTAKA}

Adamiak, C. (2018). Mapping Airbnb supply in European cities. Annals of Tourism Research, 71, 67-71. https://doi.org/10.1016/j.annals.2018.02.00 8

Brownstein, N. C., Adolfsson, A., \& Ackerman, M. (2019). Descriptive statistics and visualization of data from the $\mathrm{R}$ datasets package with implications for clusterability. Data in Brief, 25, 104004. https://doi.org/10.1016/j.dib.2019.104004

Diamond, M., \& Mattia, A. (2017). Data Visualization: An Exploratory Study into the Software Tools Used by Businesses.
Journal of Instructional Pedagogies, 18. https://eric.ed.gov/?id=EJ1151731

Gunter, U. (2018). What makes an Airbnb host a superhost? Empirical evidence from San Francisco and the Bay Area. Tourism Management, 66, 26-37. https://doi.org/10.1016/j.tourman.2017.11. 003

Gunter, U., Önder, I., \& Zekan, B. (2020). Modeling Airbnb demand to New York City while employing spatial panel data at the listing level. Tourism Management, 77, 104000.

https://doi.org/10.1016/j.tourman.2019.104 000

Hoelscher, J., \& Mortimer, A. (2018). Using Tableau to visualize data and drive decision-making. Journal of Accounting Education, 44, 49-59. https://doi.org/10.1016/j.jaccedu.2018.05.0 02

Kui, X., Liu, W., Xia, J., \& Du, H. (2017). Research on the improvement of python language programming course teaching methods based on visualization. 2017 12th International Conference on Computer Science and Education (ICCSE), 639-644. https://doi.org/10.1109/ICCSE.2017.80855 71

Liang, S., Schuckert, M., Law, R., \& Chen, C.-C. (2017). Be a "Superhost": The importance of badge systems for peer-to-peer rental accommodations. Tourism Management, 60, 454-465. https://doi.org/10.1016/j.tourman.2017.01. 007

Ridzuan, F., \& Wan Zainon, W. M. N. (2019). A Ulasan on Data Cleansing Methods for Big Data. Procedia Computer Science, 161, 731-738. https://doi.org/10.1016/j.procs.2019.11.177

Setiawan, I. (2020). ANALISIS DAN VISUALISASI HOST LIBURAN SINGKAT MENGGUNAKAN PENDEKATAN ANALISIS GEOSPASIAL. JTT (Jurnal Teknologi Terapan), 6(1), 1-7. https://doi.org/10.31884/jtt.v6i1.249

Sutherland, I., \& Kiatkawsin, K. (2020). Determinants of Guest Experience in Airbnb: A Topic Modeling Approach Using LDA. Sustainability, 12(8), 3402. https://doi.org/10.3390/su12083402 